\title{
Potential distribution model of Ovis canadensis in northern Baja California, Mexico
}

\author{
Enrique de Jesús Ruiz-Mondragón ${ }^{1}$, Guillermo Romero-Figueroa ${ }^{1 *}$, Mario Alberto García-Aranda ${ }^{2}$, \\ Eloy Alejandro Lozano-Cavazos ${ }^{3}$ and Raúl Valdez 4 . \\ ${ }^{1}$ Laboratorio de Manejo y Conservación de Vida Silvestre, Facultad de Ciencias, Universidad Autónoma de Baja California. \\ Carretera Ensenada-Tijuana 3917, CP. 22860, Ensenada. Baja California, México. Email: enrique r m7@hotmail.com (EJRM), \\ gromero4@uabc.edu.mx (GRF). \\ 2 Departamento Forestal, Universidad Autónoma Agraria Antonio Narro. Calzada Antonio Narro 1923, CP. 25315, Saltillo. Coahuila, \\ México. Email: magarcia silvae@hotmail.com (MAGA) \\ ${ }^{3}$ Departamento de Recursos Naturales Renovables, Universidad Autónoma Agraria Antonio Narro. Calzada Antonio Narro 1923, \\ CP. 25315, Saltillo. Coahuila, México. Email: alejandrolzn@yahoo.com (EALC). \\ ${ }^{4}$ Department of Fish, Wildlife and Conservation Ecology, New Mexico State University. Las Cruces 88001. New Mexico, U. S. A. \\ Email: rvaldez@ad.nmsu.edu (RV). \\ ${ }^{*}$ Corresponding author
}

The bighorn sheep is an iconic species in Baja California, being a key element for environmental conservation across its distribution range due to the huge dimensions of its habitat. In this regard, priority areas should be identified to propose feasible management practices. In this context, ecological niche models are essential because they are important methodological tools that indicate the suitability of the habitat for proper species development, based on field observations and multiple environmental variables as occupancy predictors. This investigation aims to identify the potential distribution range of the bighorn sheep in Sierra de Juarez using an ecological niche model. Indirect signs of the presence of bighorn sheep were sampled in Sierra de Juárez from January to June 2016 in order to gather evidence of the species, along with records from an aerial survey carried out in 2012. The ecological niche model was constructed applying the maximum-entropy algorithm assisted with the Maxent software. Ruggedness, orientation, slope, normalized difference vegetation index (NDVI), type of vegetation, and type of weather were used as predictive variables. In Sierra de Juarez, bighorn sheep inhabit an area of 49,844 ha with the following characteristics: climates ranging from very arid semi-warm $\left[\mathrm{BWh}\left(\mathrm{x}^{\prime}\right)\right]$ to very arid temperate $\left[\mathrm{BWk}\left(\mathrm{x}^{\prime}\right)\right.$ and $\left.\mathrm{BWks}\right]$; natural vegetation comprising gallery and palm-tree patches; NDVI of 0.05 to 0.07 ; orientation of 0 to $160^{\circ}$; slope of 0 to $65 \%$; and ruggedness of 35 to $160 \mathrm{~m}$ (Figure 4). NDVI, vegetation type and ruggedness were the variables with the greatest contribution to the ecological niche model (Table 1). Bighorn sheep are distributed primarily in the northern and central regions of Sierra de Juárez (Figure 2). According to the niche model, these areas have environmental conditions that provide shelter and resources for this species. Therefore, it is hereby proposed to organize the local landowners to implement actions to protect the bighorn sheep habitat to warrant the conservation of this iconic species and its environment in the region studied.

El borrego cimarrón es una especie emblemática la cual representa en sus zonas de distribución un elemento clave para la conservación de su entorno, que debido a las extensas dimensiones de su hábitat requiere de la ubicación de regiones prioritarias dentro de este, con el objetivo de proponer estrategias de manejo factibles. Es en este contexto que los modelos de nicho ecológico cobran importancia al ser herramientas metodológicas que indican la idoneidad del hábitat para el establecimiento de una especie, calculada a partir de observaciones de campo y una serie de variables ambientales que actúan como predictores. El objetivo de la presente investigación es identificar la distribución potencial para el borrego cimarrón en Sierra Juárez, empleando un modelo de nicho ecológico. Se realizó un rastreo de evidencias de la presencia del borrego cimarrón en Sierra Juárez de enero a junio de 2016, para generar una base de datos de registros geográficos de la especie, la cual se complementó con los registros obtenidos de un censo aéreo efectuado en el sitio en 2012. El modelo de nicho ecologico se generó mediante el algoritmo de máxima entropía ejecutado por el programa Maxent empleando como variables predictivas la escabrosidad, la orientación, la pendiente, el índice de vegetación de diferencia normalizada (NDVI), el tipo de vegetación y el tipo de clima. El borrego cimarrón en Sierra Juárez se distribuye en un área de 49,844 ha (Figura 2), donde su presencia es más probable en sitios con: climas muy árido semicálido [BWh(x')], muy árido templado $\left[\mathrm{BWk}\left(\mathrm{x}^{\prime}\right)\right]$ y muy árido templado [BWks]; vegetación de tipo galería y palmar natural; NDVI de 0.05 a 0.07 ; orientación de 0 a $160^{\circ}$; pendiente de 0 a 65 \%; y escabrosidad de 35 a 160 m (Figura 4). y Siendo el NDVI, el tipo de vegetación y la escabrosidad, las variables de mayor contribución para la creación del modelo de nicho ecológico (Tabla 1). Potencialmente el borrego cimarrón se distribuye en las regiones del norte y centro de Sierra Juárez (Figura 2), ya que de acuerdo con el modelo de nicho estas zonas presentan condiciones ambientales que le brindan cobertura y recursos a la especie. Por lo que se propone organizar a los propietarios de estas regiones prioritarias para llevar a cabo acciones de protección y mantenimiento del hábitat, que aseguren la conservación de esta emblemática especie y su entorno.

Key words: desert bighorn sheep; ecological niche model; potential distribution model; Sierra de Juárez; wild sheep.

@ 2018 Asociación Mexicana de Mastozoología, www.mastozoologiamexicana.org

\section{Introduction}

In Mexico, the bighorn sheep is an iconic species naturally distributed across the Baja California peninsula and the state of Sonora; populations maintained under semi-captivity exist in the states of Chihuahua and Coahuila ( $\underline{\text { San- }}$ doval and Espinoza 2001; Sánchez 2005; Uranga and Valdez 2011). In these areas, this species contributes to the ecosystem production chain by consuming plant resources and as a source of energy for large predators and scavengers (Monson 1980). In addition, it represents a key ele- 
ment for the conservation of its habitat, mainly due to its importance as a game species, since the prices of permits for legal hunting are high, ranging between $\$ 45,000$ and $\$ 60,000$ USD (Lee 2011; Ruiz 2014).

The sustainable use of the species requires the development of a comprehensive and adaptive management plan, designed based on scientific information addressing the needs and interests of the managers of this resource (Walters 1986; Mandujano 1994). However, the dimensions of the bighorn sheep habitat are far too extensive to propose feasible management strategies, thus making it necessary to identify the sites of higher probability of occurrence of individuals of this species to focus conservation efforts on them (Lara et al. 2001; Escobar et al. 2015).

Studies on habitat preferences of bighorn sheep in the Baja California peninsula and Sonora, using use-availability methods, methodologies based on generalized linear models, and satellite remote sensing techniques, have shown that the species does not use habitat resources according to their abundance, as some are preferred while others are clearly overlooked. Elevation, slope, ruggedness and plant cover are the characteristics of the habitat that determine the sites preferred by the species (López et al. 1999; Lara et al. 2001; Guerrero et al. 2003; Escobar et al. 2015). Hence, the potential distribution of the species in a particular locality can be determined using an ecological niche model, as it is a representation of the environmental suitability for the establishment of a particular species, calculated from field observations (presence/absence) and the availability of a series of environmental variables (climate, topography, vegetation, among others) that act as predictors (Soberón and Peterson 2005; Ferrier and Guisan 2006; Naoki et al. 2006).

Although several methods to develop niche models are available, the one based on a statistical approximation named maximum entropy and run by the Maxent software (Phillips 2013) offers some unique advantages relative to others. It works with presence data only, while other models require presence and absence data; it shows a consistently good performance versus other similar methods, in differentiating between sites that are either suitable or unsuitable for the establishment of a particular species, especially with a small number of samples (Elith et al. 2006; Phillips et al. 2006; Hernández et al. 2008); also, it is freely available.

In the Baja California peninsula, the bighorn sheep is distributed from Sierra de Juarez on the border with the United States, to the Sierra de San Juan de la Costa adjacent to Bahía de La Paz (Sánchez 2005; Ruiz 2014). Sierra de Juarez is listed as a high-priority terrestrial region for biodiversity conservation in Mexico due to its physical and biotic characteristics; for being a key area for the functional connectivity for wildlife populations across the landscape, given its location in an international border; and because this mountain range is associated with six hydrological basins that flow to the main cities in the state of Baja California (CONABIO 1998; Arriaga et al. 2000; Buchalski et al. 2015).
The objective of this work was to construct a model of potential distribution for the bighorn sheep in Sierra de Juarez, to facilitate the identification of the areas of greatest importance for the species across its range. This information is key to design a management plan aimed at ensure the conservation of the species and its habitat.

\section{Materials and Methods}

Study Area. The habitat available for bighorn sheep in Sierra de Juarez is located in the area of ravines and canyons of the mountain range, which starts in the border with the United States of America in La Rumorosa and stretches southward to Valle de la Trinidad $\left(31.300^{\circ} \mathrm{N},-115.370^{\circ} \mathrm{W}\right.$ and $32.630^{\circ} \mathrm{N}$, $-116.035^{\circ} \mathrm{W}$ ), covering an area of approximately $145,105 \mathrm{ha}$. Land tenure is shared by the ejidos Emiliano Zapata, Cordillera Molina, Mission Santa Catarina, Jamau and 16 de Septiembre (RAN 2016; Figure 1).

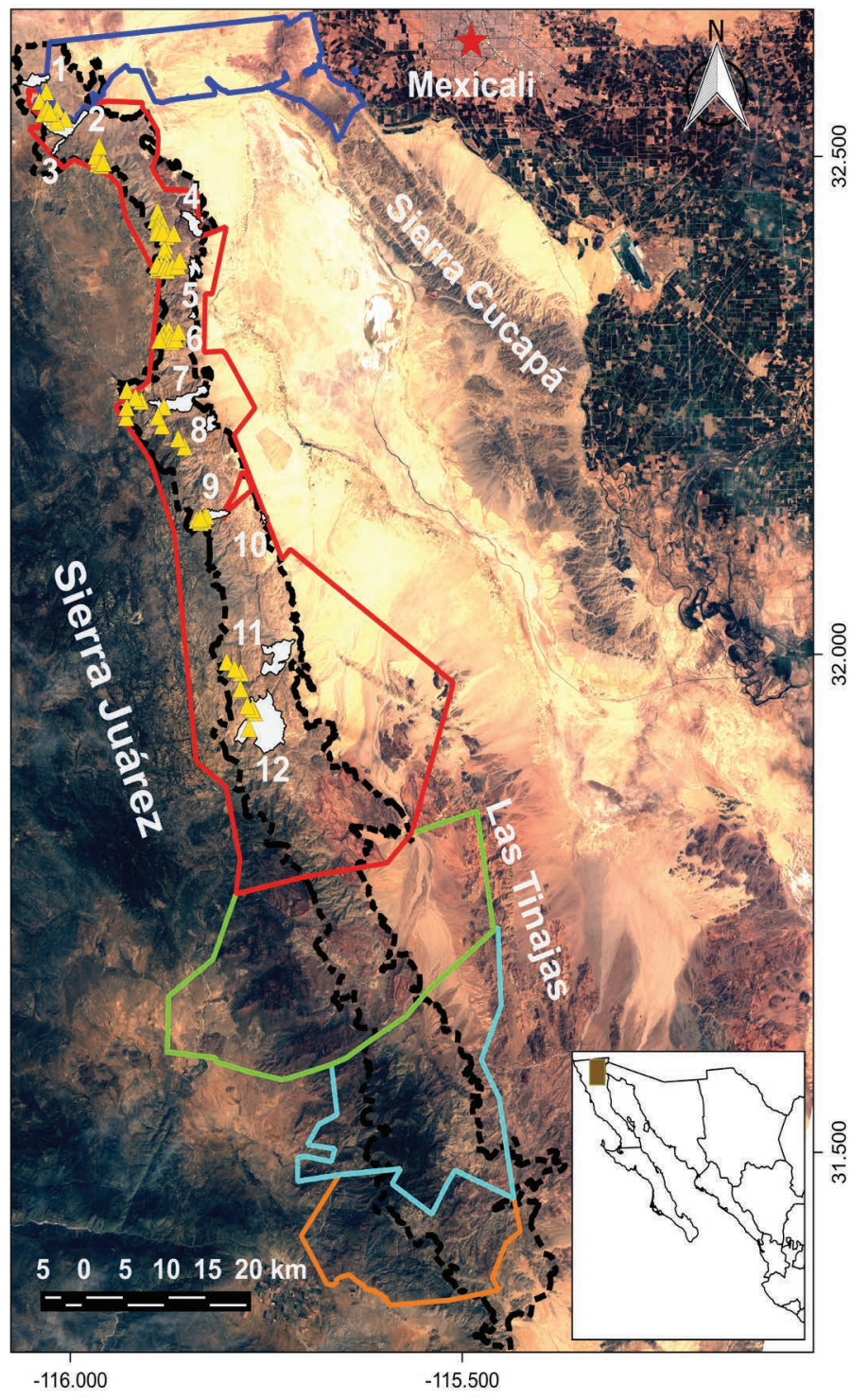

Figure 1. Study area (black dots) showing 2012 aerial census records (yellow) and sampling sites (white): 1) Cañón de Los Álamos; 2) Cañón de los Llanos; 3) Cañón del Ranchito; 4) Cerros Boludos; 5) Cerros de la Ponderosa; 6) La Rosa; 7) Cañón del Tajo; 8) Cerros de los Laureles del desierto; 9) Cañón de Guadalupe; 10) Cerros del Ejido Manatou; 11) Cañón del Alamar; 12) Cañón del Palomar. Ejidos located in the study area are: Emiliano Zapata (dark blue), Cordillera Molina (red), Misión de Santa Catarina (green), Jamau (light blue), 16 de septiembre (orange). 
Physiographically, the area is formed by an asymmetric mountain range that is steep-sloped to the east and with gentle slopes to the west. The predominant orientation in the area is to the east, with slopes between $0 \%$ and $72 \%$, dominated by those lower than $20 \%$, and most ruggedness values range between 0 and $50 \mathrm{~m}$, with a maximum of 228 m (INEGI 2013).

Six vegetation types cover the study area: pine forest in the highest peaks, chaparral scrubs growing along the western slope, microphyll desert scrub to the east, rosetteshaped desert scrub patches, natural palm-tree patches in the bottom of canyons with water availability all year round, and gallery vegetation along riverbanks (INEGI 2013).

Sierra de Juárez shows five types of climates in ravines: very arid, semi-warm $\left[B W h\left(x^{\prime}\right)\right]$; very arid, temperate with rainfall throughout the year $\left[\mathrm{BWk}\left(\mathrm{x}^{\prime}\right)\right]$; very arid, temperate with winter rainfall [BWks]; temperate [Cs]; and sub-humid semi-cold [CB's] (García and CONABIO 1998).

Construction of the database on bighorn sheep evidence. Twelve sites were selected for being recognized by Sierra de Juárez local inhabitants as bighorn sheep distribution areas between La Rumorosa and Cañón del Palomar, which were traveled from January to June 2016 (Figure 1). In each site, one transect was established, the length of which varied according to accessibility, ranging between $2 \mathrm{~km}$ and $24 \mathrm{~km}$ long. The presence of bighorn sheep was recorded and geo-referenced in each individual transect through indirect evidence (excreta and footprints), discarding those records separated from each other by less than $30 \mathrm{~m}$, to avoid over-fitting.

The database was supplemented with records of the aerial census conducted by the San Diego Zoo in 2012, where four persons flew over Sierra de Juárez for 10 hours on board a Hughes $500^{\mathrm{TM}}$ helicopter with doors removed, from La Rumorosa to Valle de la Trinidad (García 2014; Figure 1).

Environmental Characteristics of the Study Area. We used the free software QGIS 2.8.6 (QGIS Development Team 2016) for geospatial data handling and processing. This software processed the information of a digital terrain model corresponding to the study area, with a spatial resolution of $30 \times 30 \mathrm{~m}$ pixel (INEGI 2013). We calculated the area covered by particular orientation, slope and ruggedness index data, the latter estimated with the method by Riley et al. (1999). The vector information regarding the land-use and vegetation layer of the study area (INEGI 2013) was rasterized to a $30 \times 30$ $\mathrm{m}$ pixel resolution, preserving the vegetation type field.

Plant cover was estimated from Landsat $8 \mathrm{OLI} / \mathrm{TIRS}$ satellite images (039 Path, 038 Row) for 21 April 2016, with a 30 × 30 $m$ pixel resolution (USGS 2016), using the calculated value of a Normalized Difference Vegetation Index (NDVI), where NDVI = [(Band 5 - Band 4) / (Band 5 + Band 4)] (Purevdorj et al 1998; Pettoreli 2013). With this index, a value between -1 to 1 is assigned to each pixel in the matrix of the study area, where figures below 0.1 correspond to rocky outcrops with sparse vegetation, those between 0.2 and 0.5 to scrubs and grasslands, and those from 0.5 to 1 to forests and cropland (USGS 2015).

The types of climates in the study area were updated using high-resolution climate areas for Mexico (Cuervo et al. 2014). These were interpolated to a $30 \times 30 \mathrm{~m}$ pixel resolution with the thin-plate interpolation technique using the software ANUSPLIN 4.3 (Hutchinson 2006). The parameters of climate surface areas were combined to produced updated types of climates, by entering the respective data into the PATN.EXE 3.1.2.0 program (PATN Development Team 2013), and conducting a cluster analysis with mixed variables using the Gower's similarity coefficient. The resulting climate types were classified according to the nomenclature used by García and CONABIO (1998).

Potential Distribution Modelling. An ecological niche model was constructed using the Maximum Entropy algorithm with the software Maxent version 3.3.3k (Phillips 2013). The database of bighorn sheep evidence records were entered, along with the GIS information layers for orientation, slope, ruggedness index, climate types, vegetation types and NDVI.

The algorithm implementation was used to construct a model of average values, performing 20 replicates with 1,000 iterations each, where $80 \%$ of occurrence records were used for constructing the model and $20 \%$ for the test analysis, by activating the Random seed option in order to use different occurrence localities in each replicate for the construction of the models. A regularization factor $\beta$ of 1 was used, disabling the Extrapolate and Do clamping options to avoid data overfitting. The selected output was Logistic, which classifies pixel values according to a zeroto-one scale, and interprets the scale as the probability of occurrence of the species (Phillips et al. 2006).

The predictive accuracy of the model was determined by calculating the area under the curve (AUC) of the receiver operating characteristic (ROC). The fraction of sites misclassified as absences (omission errors) was determined by calculating the omission rate and the average predicted area (Phillips et al. 2006). The model obtained was reclassified to produce a binary (presence-absence) map, where a cut-off threshold was applied for presence of training data points (Pearson et al. 2007). Model variables were assessed through a Jacknife test, which yielded the information and percentage contributed by each variable. In addition, response curves were plotted to relate bighorn sheep presence data with each environmental variable used to elaborate the maximum-entropy model (Phillips et al. 2006).

\section{Results}

A total of 196 bighorn sheep records of were obtained, with 116 corresponding to indirect evidence of its presence found during transect walks carried out from January to June 2016, and 80 to direct observations of individuals during the 2012 aerial census (Figure 1). The potential distribution range of the species covers 49,844 ha $(34.3 \%)$ of Sierra de Juárez, an area that is concentrated to the northern 


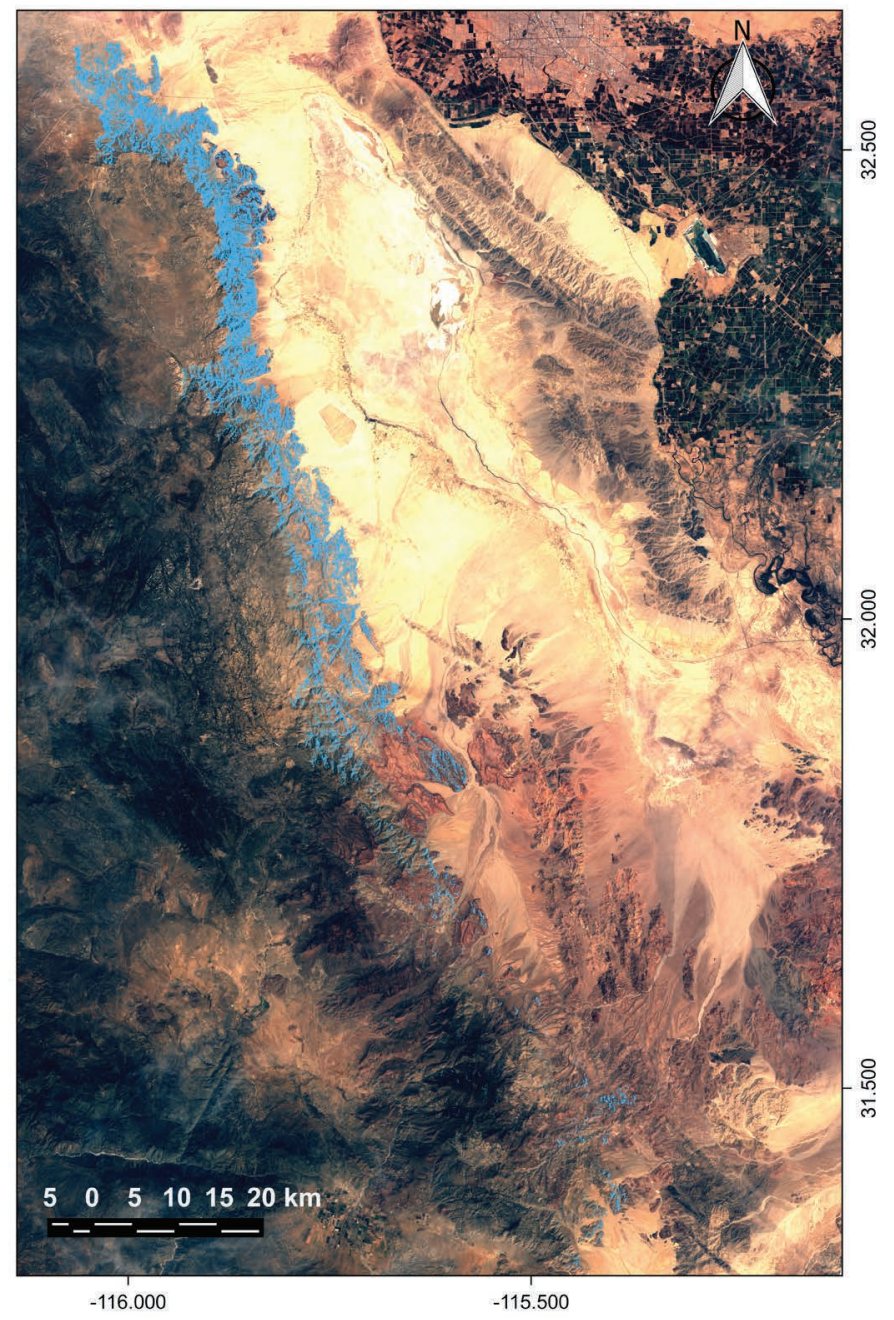

Figure 2. Potential distribution of bighorn sheep in Sierra de Juárez (blue).

region of the cordillera and drops steadily toward the south of the mountain range, being finally scattered in patches in areas near Sierra de Las Tinajas (Figure 2).

The omission rate and predicted area showed that omission in test points did not fully match the predicted omission rate (Figure 3a). For its part, the area under the curve

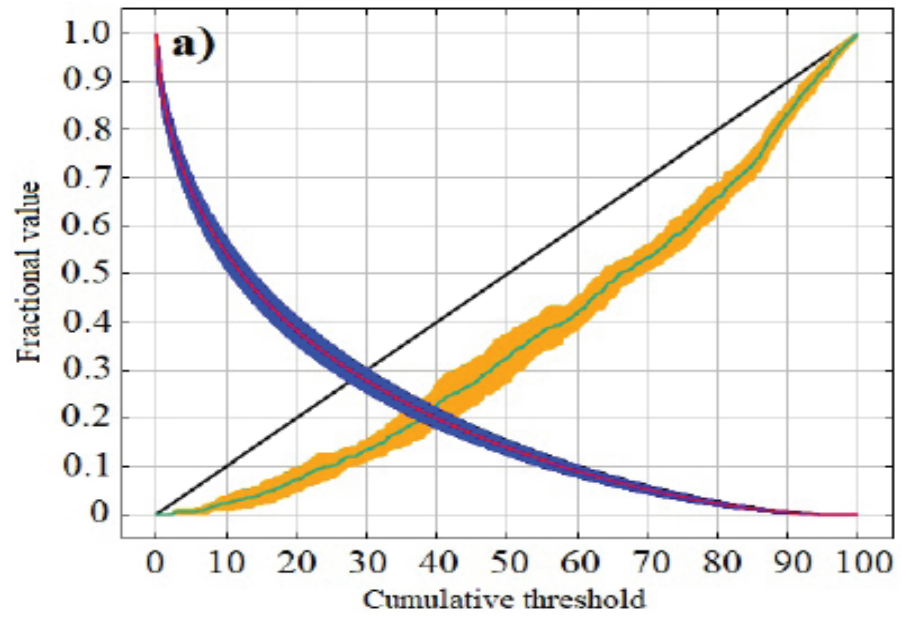

Table 1. Relative contribution (in percentage) of topographical and environmental variables in the construction of the bighorn sheep potential distribution model in Sierra de Juárez.

\begin{tabular}{lc}
\hline Variable & Contribution (\%) \\
\hline Plant cover & 26.7 \\
Vegetation type & 24.1 \\
Ruggedness & 22.2 \\
Climate & 11.8 \\
Orientation & 10.3 \\
Slope & 4.9 \\
\hline
\end{tabular}

(AUC) of the receiver operating characteristic $(\mathrm{ROC})$ yielded a model with a value of 0.877 and a standard deviation of 0.011 (Figure 3b). Taken together, the variables plant cover $(26.7 \%)$, vegetation type $(24.1 \%)$, and ruggedness $(22.2 \%)$ contributed with $73 \%$ of the information necessary for the construct of the model (Table 1).

The response curves generated by the potential distribution model show that the highest probability of bighorn sheep encounter occurs in sites with the following characteristics: very dry semi-warm $\left[B W h\left(x^{\prime}\right)\right]$, very arid temperate $\left[\mathrm{BWk}\left(\mathrm{x}^{\prime}\right)\right]$ and very arid temperate [BWks] climates; gallery and natural palm-tree vegetation; NDVI from 0.05 to 0.07 ; orientation from 0 to $160^{\circ}$; slope from 0 to $65 \%$; and ruggedness from 35 to $160 \mathrm{~m}$ (Figure 4).

\section{Discussion}

The potential distribution range of the bighorn sheep covers regions of northern and central Sierra de Juarez, as according to the niche model these have environmental conditions that provide shelter and resources to the species (Soberón and Peterson 2005). However, the modeling reported here should be regarded as a partial instrument, as the closeness between the localities where the species was recorded led to an overfitting of the data caused by the dependency between data points (Figure 3a). The end result is that the distribution area identified for the bighorn sheep was smaller than the true area. However, the model

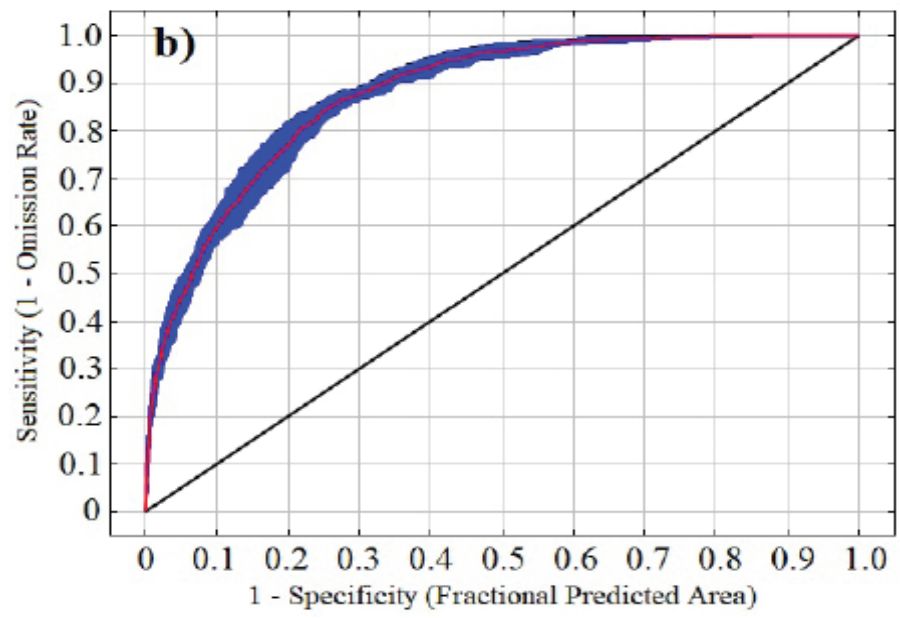

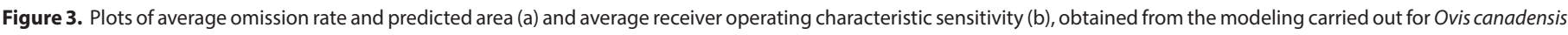

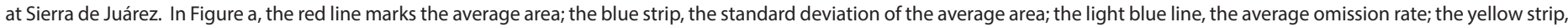

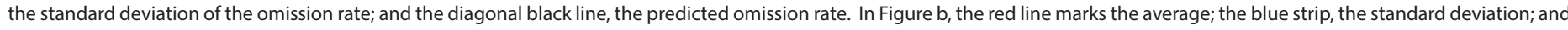
the black diagonal, the expected line if the model is not better than a random one. 
functions properly to differentiate between sites with high vs. low probability of bighorn sheep occurrence (Figure 3b; Phillips et al. 2006).

In the model, vegetation was the primary component of the habitat that explained most of the bighorn sheep distribution in Sierra de Juarez (Table 1). It provides food resources for the species, is an indicator of water availability, and is closely related to its anti-predatory strategy (Monson 1980; Wilson et al. 1980; Holl 1982; Álvarez et al. 2009; Escobar et al. 2015). The type of vegetation that predominates in regions identified as distribution areas of bighorn sheep is microphyll desert scrub (INEGI 2013). This includes shrubs and herbs of importance as food sources for the bighorn sheep, such as Ephedra nevadensis, Eriodyc-
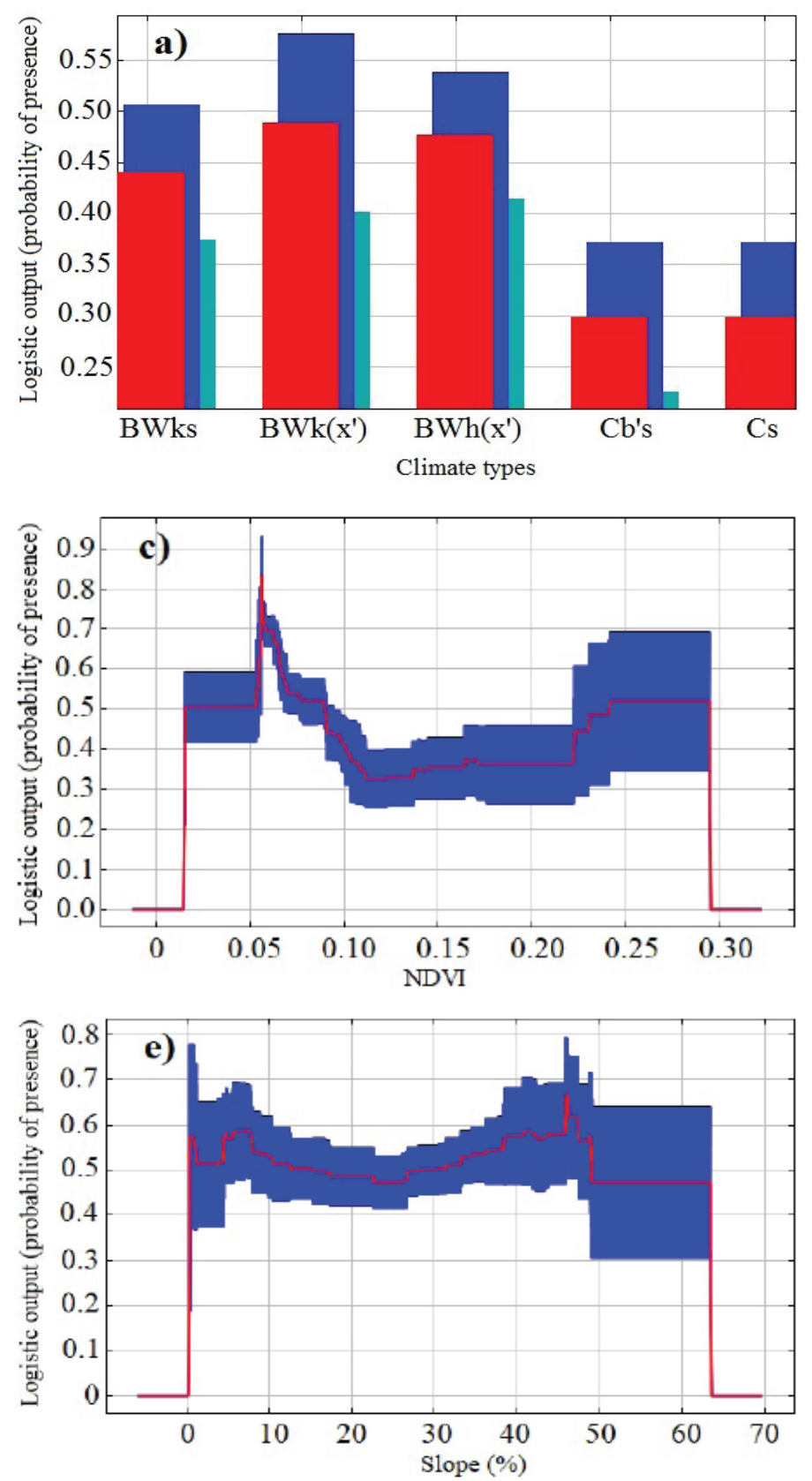

tion angustifolium, Senecio spartioides, Ceanothus gregii, Eriogonum fasciculatum, Simmondsia chinensis, Ditaxis lanceolata, Galium wigginsii, Cardiospermum corindum, Bromus ciliatus, Erioneuron pulchellum, Ferocactus sp. and Agave sp. (Reyes, 1976; Sánchez, 1978). In addition, this plant community has a low vegetation index (NDVI $=0.05$ to 0.07 ), providing more visibility or lesser visual obstruction for the detection of predators (Monson 1980; Wilson et al. 1980; Holl 1982; Álvarez et al. 2009; Escobar et al. 2015).

The response of the distribution of organisms to the slope turned out to be indifferent (Figure 4), in contrast with the findings reported by López et al. (1999), and Guerrero et al. (2003), who concluded that the desert sheep evades sites with slopes below than $60 \%$. This situation is
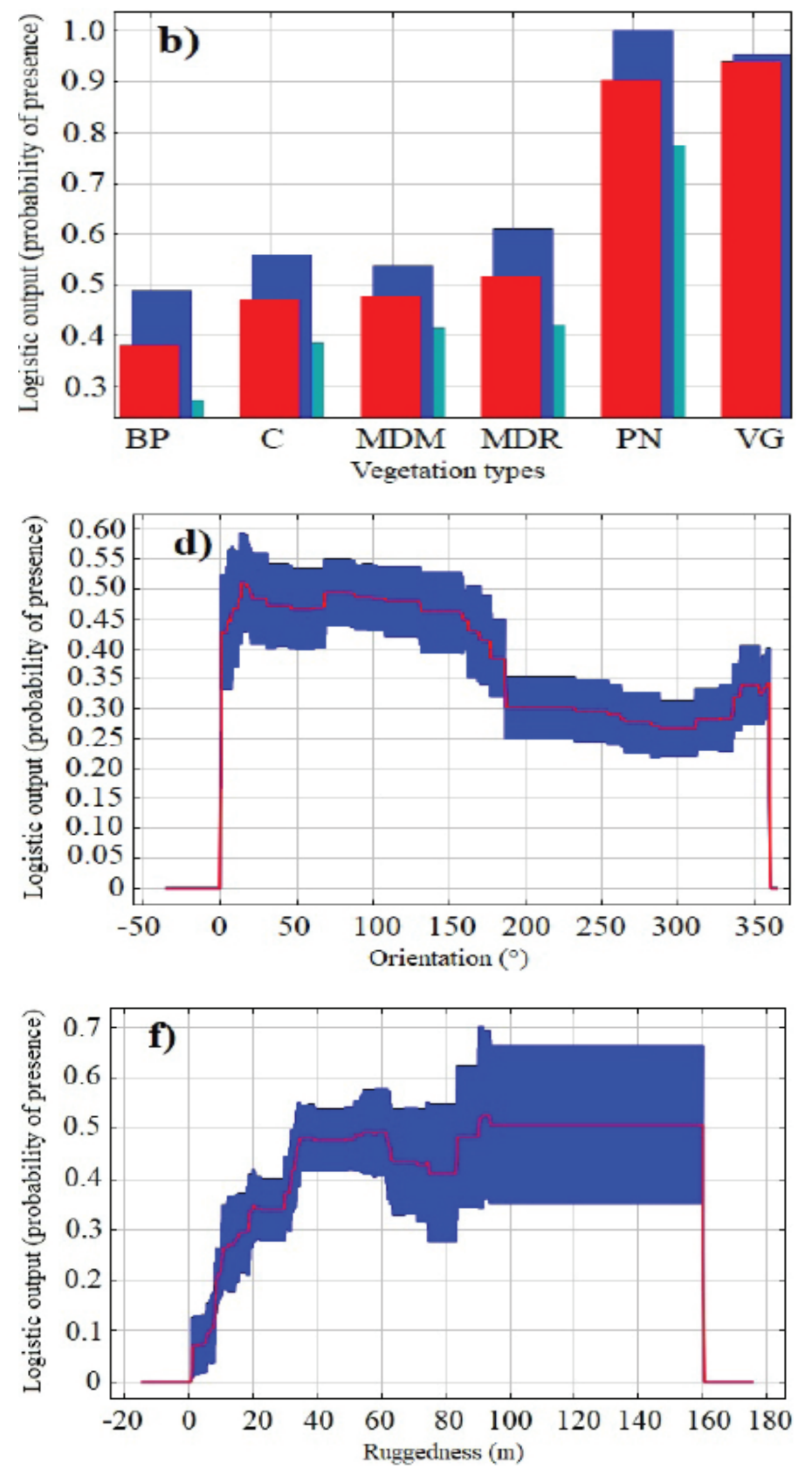

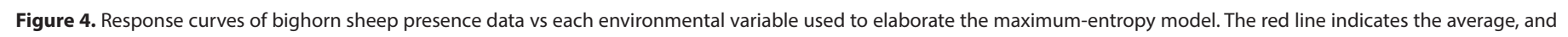

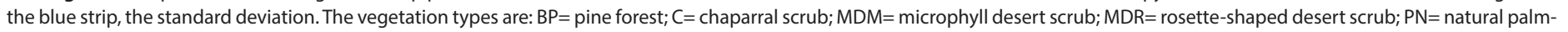
tree forest; $\mathrm{VG}=$ gallery vegetation . 
attributed to the fact that the suitability values of topography vary according to the scale used (Divine et al. 1996). Differences may stem from the fact in the studies just mentioned, the slope was measured in the field, so that the true value was recorded on site. By contrast, in our study slope was calculated from a digital terrain model with a $30 \times 30$ $\mathrm{m}$ resolution; this approach involves intrinsic inaccuracies related to the original source of the data used to elaborate it, and to the interpolation of elevations that do not represent the true altitude of the terrain for a particular location. In addition, the accuracy of the elevation models is higher in flat versus rugged areas (Riley et al. 1999). It has been recorded that slope is a structural element of minor importance in the elaboration of models of the potential distribution of wild ungulates that inhabit mountainous areas; in contrast, vegetation, climate and the anthropic component are the variables with the greatest influence on their distribution (Keya et al. 2016; Khan et al. 2016).

Ruggedness was one of the variables with the highest contribution to the potential distribution model (Table 1). This variable is related to the proportion of land that facilitates the escape of the species, resulting from the calculation of relief heterogeneity (Riley et al. 1999; Escobar et al. 2015). Relatively smooth land (35 to $160 \mathrm{~m}$ ) was associated with the peninsular distribution of the bighorn sheep in Sierra de Juárez (Figure 4). These results are consistent with those recorded in the Santa Isabel and Mechudo mountain ranges by Álvarez (2009) and Escobar et al. (2015). In this areas, the bighorn sheep is associated with ruggedness values between $21 \mathrm{~m}$ and $267 \mathrm{~m}$, typical of mid- and highaltitude sierras with ravines that offer protection to sheep herds.

The distribution of the bighorn sheep was found to be related to natural palm-tree and gallery patches (Figure 4), both of which are associated with surface water bodies. Likewise, it was found that bighorn sheep individuals thrive along slopes facing east (Figure 4), consistent with the findings reported for Sierra del Mechudo by Guerrero et al. (2003), as this is the prevailing slope orientation in both mountain ranges. As regard climate, the very arid semiwarm $\left[\mathrm{BWh}\left(\mathrm{x}^{\prime}\right)\right]$, very arid temperate $\left[\mathrm{BWk}\left(\mathrm{x}^{\prime}\right)\right]$, and very arid temperate [BWks] types were also associated with the distribution of the species (Figure 4).

The data obtained can be used as a baseline to elaborate an integrated management plan of the bighorn sheep habitat in Sierra de Juárez with the strategic aim to organize the resource owners in a monitoring group. Regular inspections to the bighorn sheep distribution area should be conducted in order to prevent poaching and habitat disruption. In addition, its populations should be monitored, and water bodies used by them should be kept in good condition. Another objective should be to promote the productive diversification of sites with tourism potential, equipping ranches adjacent to bighorn sheep areas to increase their capabilities to conduct nature-tourism activities in sites that are key for the bighorn sheep and that are currently used as rangeland. The above are measures that will contribute to the conservation of this iconic species and its environment.

\section{Acknowledgments}

We would like to thank the following persons and institutions: to CONACyT, for the scholarship to undertake postgraduate studies granted to E. J. Ruiz Mondragón; to UABC, for financing the project "Ecological Niche Modeling of Ungulates in Sierra de Juárez" as part of the first special internal call; to Ejido Cordillera Molina for allowing us access to their land; to A. Guevara and J. Reyes for facilitating the material needed to conduct field work; to O. Tellez for support in gathering climate information for the study area; and to M. I. Ruiz for support in the edition of the abstract. María Elena Sánchez-Salazar translated the manuscript into English.

\section{Literature Cited}

Álvarez, C., T. Gallina, C. Díaz, I. Guerrero, V. Castellanos, and Z. Mesa. 2009. Evaluación de elementos estructurales del hábitat del borrego cimarrón en la Sierra del Mechudo, Baja California Sur, México. Tropical Conservation Science 2:189-203.

Arriaga, L., J. Espinoza, C. Aguilar, E. Martínez, L. Gómez, and E. Loa. 2000. Regiones Terrestres Prioritarias de México. Comisión Nacional para el Conocimiento y Uso de la Biodiversidad. Distrito Federal, México.

Buchalski, M., A. Navarro, W. Boyce, T. Vickers, M. Tobler, L. Nordstrom, J. Alaniz, D. Gille, M. Penedo, O. Ryder, And H. Ernest. 2015. Genetic population structure of peninsular bighorn sheep (Ovis canadensis nelsoni) indicates substantial gene flow across USMexico border. Biological Conservation 184:218-228.

Comisión Nacional para el Conocimiento y Uso de la Biodiversidad (CONABIO). 1998. Subcuencas Hidrológicas escala 1:1000000. http://www.conabio.gob.mx/informacion/gis/. Consultada en abril de 2016.

Cuervo, A., O. Téllez, M. Gómez, C. Venegas, J. Manjarrez, and E. MARTínez. 2014. An update of high-resolution monthly climate surfaces for Mexico. International Journal of Climatology 34:2427-2437.

Divine, D., E. Donald, And C. Douglas. 1996. Effects of the scale defining topographically suitable desert bighorn sheep habitat. Desert Bighorn Council Transactions 40:13-18.

Elith, J., C. Graham, R. Anderson, M. Dudík, S. Ferrier, A. Guisan, R. Himmans, F. Huettmann, J. Leathwick, A. Lehmann, J. LI, L. Lohmann, B. Loiselle, G. Manion, C. Moritz, M. Nakamura, Y. Nakazawa, J. Overton, T. Peterson, S. Phillips, K. Richardson, R. Scachetti, R. Schapire, J. Soberón, S. Williams, M. Wisz, AND N. Zimmermann. 2006. Novel methods improve prediction of species' distributions from occurrence data. Ecography 29:129-151.

Escobar, J., S. Álvarez, R. Valdez, J. Torres, S. Díaz, A. Castellanos, and R. MARTínez. 2015. Detección de las preferencias de hábitat del borrego cimarrón (Ovis canadensis) en Baja California, mediante técnicas de teledetección satelital. Therya 6:519-534.

FERRIIR, S., AND A. GUISAN. 2006. Spatial modelling of biodiversity at the community level. Journal of Applied Ecology 43:393-404.

García, E., and Comisión Nacional para el Conocimiento y Uso de la BIodiversidAD (CONABIO). 1998. Climas, Escala 1:1 000000 
http://www.conabio.gob.mx/informacion/gis/. Consultada en abril de 2016.

GARCíA, O. 2014. Caracterización de Hábitat del Borrego Cimarrón (Ovis canadensis) en la Sierra de Juárez, Baja California, México. Tesis de Licenciatura (Agrobiología), Universidad Autónoma Agraria Antonio Narro, Coahuila, México.

Guerrero, I., I. Tovar, AND Álvarez S. 2003. Factores que afectan la distribución espacial del borrego cimarrón Ovis canadensis weemsi en la Sierra del Mechudo, B.C.S., México. Anales del Instituto de Biología. Universidad Nacional Autónoma de México. Serie Zoología 74:83-98.

Hernández, P., I. Franke, S. Herzog, V. Pacheco, L. Paniagua, H. Quintana, A. Soto, J. Swenson, C. Tovar, and Valoui T. 2008. Predicting species distributions in poorly studied landscapes. Biodiversity and Conservation 17:1353-1366.

HoLL, S. 1982. Evaluation of bighorn sheep habitat. Desert Bighorn Council Transactions 26:47-49.

HutCHINSON, F. 2006. Anusplin Version 4.36 User Guide. Centre for Resource and Environmental Studies. Canberra, Australia. instituto Nacional de Estadistica, Geografía e Informática (INEGI). 2013. Conjunto de datos vectoriales de uso de suelo y vegetación, Escala 1:250 000, Serie V http://www.conabio. gob.mx/informacion/gis/. Consultada en abril de 2016.

instituto Nacional de Estadística, Geografía e Informática (INEGI). 2013. Continuo de Elevaciones Mexicano, 3.0. http://www. inegi.org.mx/geo/contenidos/datosrelieve/continental/ descarga.aspx. Consultada en mayo de 2016.

Keya, Z., S. Faryadi, A. Yavari, Y. Kamalı, And A. Shabani. 2016. Habitat suitability \& connectivity of Alborz wild sheep in the east of Tehran, Iran. Open Journal of Ecology 6:325-342.

Khan, B., A. Ablimit, G. Khan, A. Jasra, H. Alı, R. Alı, E. Ahmad, and M. IsmAll. 2016. Abundance, distribution and conservation status of Siberian ibex, Marco Polo and Blue sheep in Karakoram-Pamir mountain area. Journal of King Saud University-Science 28:216-225.

Lara, J., R. Martínez, and M. Montoya. 2001. Identification of prefered sites of peninsular bighorn sheep in Sierra San Pedro Martir, Baja California, using random walk simulation. Desert Bighorn Council Transactions 45:95-102.

LEE, R. 2011. Economic aspects of and the market for desert bighorn sheep. Desert Bighorn Council Transactions 51:46-49.

López, E., R. Lee, J. de Vos, R. Schweinsburg, and G. Salazar. 1999. Relación uso-disponibilidad de componentes topográficos y un modelo de calidad del hábitat para el borrego cimarrón, en Sonora, México. Acta Zoológica Mexicana 76:17-34.

Mandujano, S. 1994. Método para evaluar el hábitat del venado cola blanca en un bosque de coníferas. Pp. 283-297 in Ecología y manejo del venado cola blanca en México y Costa Rica (Vaughan, C., and M. Rodríguez, eds.). Universidad Nacional. Exuma, Costa Rica.

Monson, G. 1980. The Desert Bighorn. The University of Arizona Press. Tucson, U. S. A.

NAOKI, K., M. GÓmeZ, R. LópeZ, AND J. VARGaS. 2006. Comparación de modelos de distribución de especies para predecir la distribución potencial de vida silvestre en Bolivia. Ecología en Bolivia 41:65-78.

PATN Development Team. 2013. PATN.eXE pattern analysis software package, Versions: 3.1.2.0 http://www.patn.com. au/about/default.htm. Consultada en octubre de 2016.
Pearson, R. G., C. J. Raxworthy, M. Nakamura, and A. T. Peterson. 2007. Predicting species distributions from small numbers of occurrence records: a test case using cryptic geckos in Madagascar. Journal of Biogeography 34:102-117.

Pettorelli, N. 2013. The normalized difference vegetation index. Oxford University Press. New York, U. S. A.

Phillips, S., R. Anderson, AND R. Schapire. 2006. Maximum entropy modeling of species geographic distributions. Ecological Modelling 190:231-259.

PHILLIPS, S. 2013. A brief tutorial on Maxent, Versions: 3.3.1. www.cs.princeton.edu / schapire/maxent/. Consultada en junio de 2016.

PureVdors, T. S., R. TatelshI, T. Ishiyama, and Y. Honda. 1998. Relationships between percent vegetation cover and vegetation indices. International Journal of Remote Sensing 19:3519-3535.

QGIS DeVelopment Team. 2016. QGIS Geographic Information System, Versions: 2.8 .6 http// qgis.osgeo.org. Consultada en febrero de 2016.

Registro Agrario Nacional (RAN). 2016. Perimetrales de los núcleos agrarios certificados, entidad federativa Baja California http://datos.ran.gob.mx/filescd/dgcat/ran da dgcat poligonos nucleos agrarios bc.kml. Consultada en enero de 2017.

REYES, S. 1976. Caza del borrego cimarrón en Loreto, B. C. Bosques y Fauna 14:3-14.

Riley, S., S. DeGloria, AND R. ElLIOT. 1999. A terrain ruggedness index that quantifies topographic heterogeneity. Intermountain Journal of Sciences 5:23-27.

Ruiz, E. 2014. Estado actual de la población del borrego cimarrón (Ovis canadensis weemsi) en la UMA Ejido La Purísima, Baja California Sur, México. Tesis de Licenciatura (Biología), Universidad Nacional Autónoma de México. Estado de México, México.

SÁnchez, O. 2005. Ovis canadensis Shaw, 1804. Pp. 507-509 in Los Mamíferos Silvestres de México (Ceballos, G., and G. Oliva, eds.). Fondo de Cultura Económica. Distrito Federal, México. SÁNCheZ, R. 1978. Hábitos alimenticios del borrego cimarrón. Bosques y Fauna 1: 47-55.

SAndoval, A., AND A. Espinosa. 2001. Status of bighorn management programs in Coahuila, Mexico-2000. Desert Bighorn Council Transactions 45:53-61.

Soberón, J., AND T. Peterson. 2005. Interpretation of models of fundamental ecological niches and species' distributional areas. Biodiversity Informatics 2:1-10.

Uranga, T., and R. Valdez. 2011. Reintroduction of desert bighorn sheep in Chihuahua, Mexico. Desert Bighorn Council Transaction 51:32-38.

United States Geological Survey (USGS). 2015. NDVl, the foundation for remote sensing phenology. https:// phenology.cr.usgs.gov/ndvi foundation.php. Consultada en julio de 2016.

United States Geological Survey (USGS). 2016. LC80390382016112LGN00. http://earthexplorer.usgs.gov/. Consultada en julio de 2016.

Walters, C. 1986. Adaptive Management of Renewable Resources. The Blackburn Press. British Columbia, Canada. Wilson, L., J. Blaisdell, G. Welsh, R. Weaver, R. Brigham, W. Kelly, J. YoAkum, M. Hinks, J. TuRner, AND J. DeForge. 1980. Desert bighorn 
habitat requirements and management recommendations.

Desert Bighorn Council Transaction 24:1-7.

Associated editor: Eduardo Mendoza

Submitted: Octuber 20, 2017; Reviewed: February 10, 2018;

Accepted: August 2, 2018; Published on line: August 22, 2018. 